\title{
The Eastern Metropolitan, Archiepiscopal and Episcopal Sees Under the Patriarchate of Jerusalem
}

\section{Caleb Hauser}

To cite this article: Caleb Hauser (1907) The Eastern Metropolitan, Archiepiscopal and Episcopal Sees Under the Patriarchate of Jerusalem, Palestine Exploration Quarterly, 39:1, 43-46, DOI: 10.1179/peq.1907.39.1.43

To link to this article: http://dx.doi.org/10.1179/peq.1907.39.1.43

电 Published online: 19 Jul 2013.

Submit your article to this journal $\pi$

Џll Article views: 5

Q View related articles $\sqsubset$ 


\section{THE EASTERN METROPOLITAN, ARCHIEPISCOPAL AND EPISCOPAL SEES UNDER THE PATRIARCHATE OF JERUSALEM. ${ }^{1}$}

By the Rev. Caleb Hauser.

Palestina Secunda, the Metropolitan see of Scythopolis, or Bethshan, surrounded the Sea of Galilee; Palæstina Tertia, the Metropolitan see of Petra, extended from the Mojib to beyond Elath and Mount Sinai on the south. Reaching around Palæstina Tertia to the archbishopric of Elath on the south, and around Palæstina Secunda to Mount Hermon on the north, Palæstina Quarta extended from the River Jordan and the Dead Sea unto the eastern or Syrian Desert. Of the Second and Third Palestines those sees only which were east of the Jordan-and-Arabah depression will come under our observation.

First of the archbishoprics of the Second Palestine east of Jordan is Gadeiron or Gadaron, a little see on the east extending as far as Petra (where it touched the western archbishopric of Diocaesarea) and as far as the great bridge (the extent of the archbishopric of Tiberias), and as far as the monastery of the Tithe. It was thus on the shore of Lake Galilee, from the Jisr Benât Ya'kûub on the north to a little south of Gadara (Umm Keis). Here it was adjacent to the bishopric of Pella.

The archbishopric of Meron or Meru, perhaps named after the Waters of Merom, extended on the south "to the torrent," i.e. the Yarmûk, and on the east "half-way between this see and that of Ausitis," or Palæstina Quarta, and as far as the tower of Sylitus, which we may identify with Tesîl, some 5 or 6 miles south-west of Nawâ. Before its transfer from the Metropolitan see of Bostra,

1 Accurate knowledge of the boundaries of the various sees is chiefly derived from Palmer's copy of a manuscript in the library of the Patriarchate of Jerusalem, containing a list of Metropolitan, Archiepiscopal, and Episcopal towns in the see of the Holy City of Jerusalem, Desert of the Exodus, pp. 550-554. 
or Ausitis; Meron had been a bishopric named Gaba; but as an archbishopric subject to the Patriarchate of Jerusalem, it comprised the bishoprics of Gaba, Elenopolis, Hippos, Tetrakomia, ClimaGaulanae, the village of Nais, Epheca, and Nes. Hippos and Epheca (Aphek) are well known. Clima-Gaulanae, second after Hippos, was in all probability at Sahem ej-Jaulân (the ancient Golan), near the eastern boundary of this archbishopric. Gaba, or Gabaon, was probably at el-Jibein, a little north-east of Aphek. The western boundary of this see thus passed between Aphek and the Sea of Galilee northward to the Waters of Merom.

The archbishopric of Capitolias extended as far as "the great mountain," i.e., Jebel "Ajlun, and on the left as far as the torrent which separates it from Zeni (? Meru). Undoubtedly this see extended to the Yarmûk on the north, and quite to Remtheh on the east; for it included the bishopric of Pella west of, and the bishopric of Abila north of, the bishopric of Capitolia. That of Abila probably came down to the Roman Road. From De Saulcy (Dead Sea and Bible Lands, vol. ii, p. 429) I learn that Col. Lapie (in the Itineraries published by M. de Fortia) has already proposed the identification of Capitolias with Beit er-Râs. Some of M. Lapie's measurements did not correspond with the distances given in the Itinerary of Antonine and in the Peutinger Tables. Instead of $36 \mathrm{R}$. miles from Neve to Capitolias, he computed the distance from Nawâ to Beit er-Râs at 30 R. miles. But along the roads, as indicated on the P. E. F. Map, the distance is evidently about $36 \mathrm{R}$. miles. In Peutinger's Table (Itinerary from Caesarea to Philadelphia) Capitolias is placed 16 miles from both Gadara and Edrei; whereas the distance from Beit Râs to ed-Der'aah seems to be about $21 \mathrm{R}$. miles, a difference of 5 miles. Probably a V was substituted for an X. From Beit Râs to Umm Keis Col. Lapie measured $16 \mathrm{R}$. miles, as in the Itineraries. We now have sufficient evidence for the identification. The Jerusalem manuscript shows that the bishopric of Capitolias was south of Abila. So also then the city; which, furthermore, (compare the Itineraries with Eusebius ad vocem "A $\beta \epsilon \lambda$ ) was 4 miles farther from Gadara than Abila was. The site indicated is Beit Râs. Any site farther south, or south-west would be more than 36 R. miles from Nawâ. Finally, the Arabic name, Beit Râs, seems to be equivalent to the Latin Capitolias (Râs = caput), both Capitolias and Beit Râs being in the respective languages 
appropriate (and idiomatic) names for a city on an elevation. The P.E.F. Map shows Beit Râs as the highest point in northern Gilead.

Palcestina Tertia, the Metropolitan see of Petra, included five bishoprics east of the 'Arabah : Augustopolis, Arindela, Charagmucha, Areopolis, and Helas, or Elath. Northward it extended to the river Chise or Chose, and to the river Mojib. In Chise we recognize el-Hessi, the name of a wâdy at the southern extremity of the Dead Sea. Originally the name Chise must have belonged to the upper wâdy, which is now called Wâdy Garahy, Wâdy Siddeiyeh, and Seil Garahy; the lower wâdy (now el-Hessi) was the "great torrent" which divided the archbishopric of Cyriacopolis (Kerak) from the Metropolitan see of Petra. The river Chise was between Moab and Gabet, or Gabalon. The eastern boundary of Moab was also that of the diocese of Cyriacopolis, which included the bishoprics of Charagmucha and Areopolis (Kerak and Rabbah). Gabalon (cilJeb'al) south of the river Chise, and east of Petra, was also in archbishopric, and perhaps included the bishoprics of Augustopolis and Arindela. The MS. says: "It includes all the surrounding country, and is very extensive." It probably extended to Wâdy el-Ithm and the archbishopric of Ailia. Arindela has been satisfactorily identified with Ghurundel. Augustopolis seems to be Zodocatha at el-Asdakah. The radicals (transposed) of Zodocatha, Asdakah, are represented in the Roman name Augustopolis. The territory of the bishopric of Helas; was, it is evident, that of the archbishopric of Ailia, or Aila, on the coast of the Elanitic arm of the Red Sea. The north-western boundary of this see is not given, but was probably the Desert of et-Tih. From the Red Sea it extended to Wâdy el-Ithm, presumably the southern boundary of the sees of Petra and Gabalon, and (farther east) of Ausitis, or the Fourth Palestine.

Palcestina Quarta, the Metropolitan see of Bostra (and also its only archbishopric Adria or Dria) was bounded on the south-east by a wâdy (the river Zarnarios, Zarcarios, Zarnacios), which must have been a tributary of "the great torrent" which divided it from Eila (Elath). Adria must have been adjacent to Gabalon, and the archiepiscopal city Adria was evidently Ptolemy's Adra, 55 geographical miles east, and 10 north of the Edomite Bostra. As the name Adria, or Dria does not appear (as it should) in the list of episcopal towns of Palæstina Quarta, it is probable that the Dia 
(Dias, Dyas) of that list is corrupt, and should be read Dria. Of the episcopal cities and towns of Ausitis the following have been identified: Adrasus, or Edrei, Medaba, Gerassa, Neve, Philadelphia, Esbus, Canothas, and Salton Bataneos. Others may be identified thus: Dionysia (Ptolemy's Dion) with Tibneh; Tricomia, named before Canothas (Umm el-Kenafid) with the Tricomia which in the Notitia Dignitatum Imperii Romani precedes Ziza; Goniah with Ain Jenneh, near Mahanaim ; Stanæ with Shutna, near Jebel Kafkafa; Machabera with Kh. Mukubleh, south of the same mountain; Coratha with el-Herath, south of Tell Der'ala; Belbanes with Tell Bileibil, near Tell Nimrîn; Capræ, or Vicus Capron, with Kh. elKefrein ; Purgo (? arata) with Tell Abu Feraj, just north of Wady 'Ajlun ; Ariarcha with Yerka, south of Batânah ; Clima of the east and west perhaps with Tell Dâmieh; Ariatha with 'Aireh, near

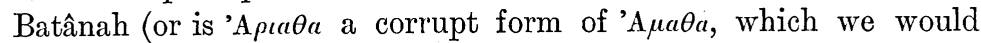
find at Tell Amateh?); Bebdamus with Abu 'Obeida, near Tell Der'ala.

The boundary of Palæstina Quarta (and of the archbishopric of Capitolias) thus passed over Jebel 'Ajlûn, and just north of Tibneh, but south of Beit Râs and Irbid, towards Remtheh and, leaving Edrei to the right, on up to Tesîl, and thence in a north-westerly direction toward Bânias. On the east, Ausitis had the Syrian Desert as far as the torrent of waters and springs (Ency. Biblica, Map of Syria, has Wady Gumar. May we read Ghamr=aqua multa ?). The remainder of the boundary has been defined as passing down the unknown river Zarcarios to the torrent (probably Wady el-Ithm) dividing this see from Eila. From this torrent it passed up to Seil Garahy, and so on to and along the eastern boundary of Moab, and along the river Mojib to the Dead Sea.

- It has been stated that the Salton Hieraticon was east of the Jordan; but it was evidently near Gaza. Furthermore, the Regeon Libiæ, between Regeon Jericho and Regeon Daron, was not at Livias, beyond the Jordan, it seems. 